\title{
GRAFIKATÖRTÉNETI ÉRDEKESSÉGEK MANIERISTA KRISZTUS-TÍPUSOK FÉNYÉBEN
}

Dr. Prokopp Mária születésnapi köszöntésére Az Úr "töltse be szíved vágyait, és váltsa valóra minden tervedet" (Zsolt 19,4)

Kevéssé ismert, hogy a rézmetszőknek is van védőszentjük. Neve: Szent Hilloin. A limousini kolostor buzgó tagjaként, szerzetesként müködött a Frank Birodalomban. Az Úr Jézus iránti szeretete találékonnyá tette. Ugyanis mindig arra gondolt, hogy miként örökíthetné meg őt. Végre megtalálta módját, amikor aranyból, ezüstből, illetve rézből lapokat készített, és finomra hegyezett vésőkkel képeket rajzolt rájuk. A kolostori évkönyvek nagy elragadtatással szólnak e müvészi alkotásokról. Nyolcvannégy éves korában halt meg, 702-ben január 7-én. A tartomány püspöke, Hernenaus testét saját karján helyezte sírba. Hilloin különösen Flandriában örvend kiváló tiszteletnek. ${ }^{1}$

Istenes Szent János (1495-1550), mielőtt megszervezte az Irgalmas rendet, katonáskodása idején még Magyarországon is járt, de eredeti mestersége könyvárus volt. Az abból szerzett összegből tartotta fenn magát. Ezért lett ő a könyvkereskedők és könyvkötők védőszentje. Ikonográfiájában teljesen ismeretlen gyüjteményem eddig nem publikált, 1770 körüli, Joseph Anton Schmidt augsburgi mester által készített, rézmetszetü szentképe, amely egykorú barokk nyomdamühelyben mutatja be, még polgári öltözetében (1. kép). ${ }^{2}$

Gottfried Bernhard Göz mellett számomra a legtöbbet jelenti Johann Andreas Pfeffel (1674-1750), akinek Augsburgban és Bécsben jelentek meg lapjai. Munkássága Augsburg érett grafikai kultúráját továbbította a bécsi mühelyekbe. Gyüjteményemben számos szentképe megtalálható, melyeknek ikonográfiai sokrétüsége figyelemre méltó. ${ }^{3}$ Fia, Johann Andreas Pfeffel junior (1715-1768) szintén rézmetsző. Megörökítette apja portréját, melyet mint ritkaságot sikerült megszereznem (2. kép). Alatta nyolcsoros, német nyelvü szöveg:



1. Joseph Anton Schmidt:

Istenes Szent János mint könyvárus, nyomdamühelyében. Rézmetszet, 1770 körül. A szerző gyüjteményében 

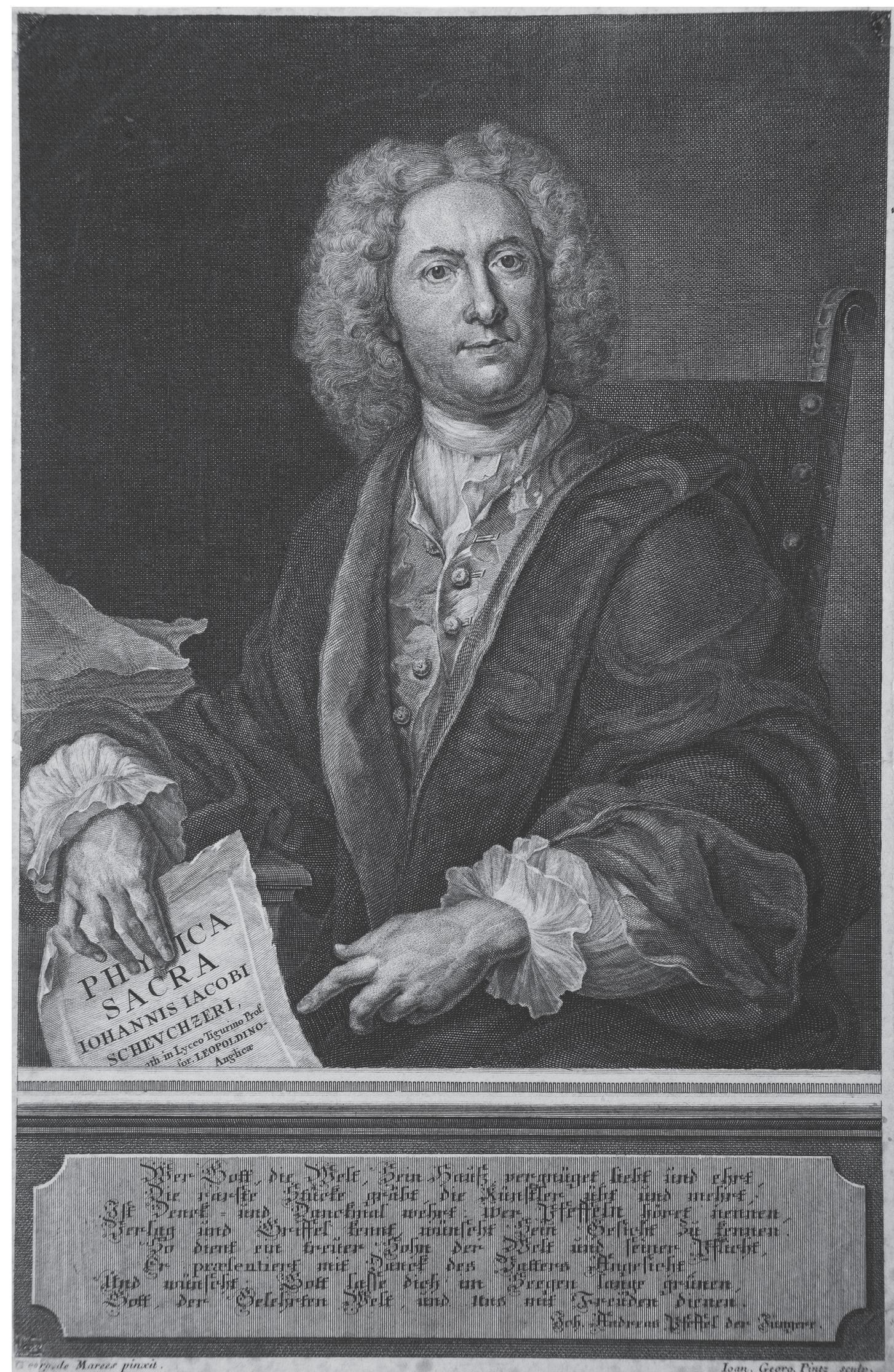

2. Ifj. Johann Andreas Pfeffel: Id. Johann Andreas Pfeffel képmása. Rézmetszet, 1750 után. A szerzö gyújteményében 


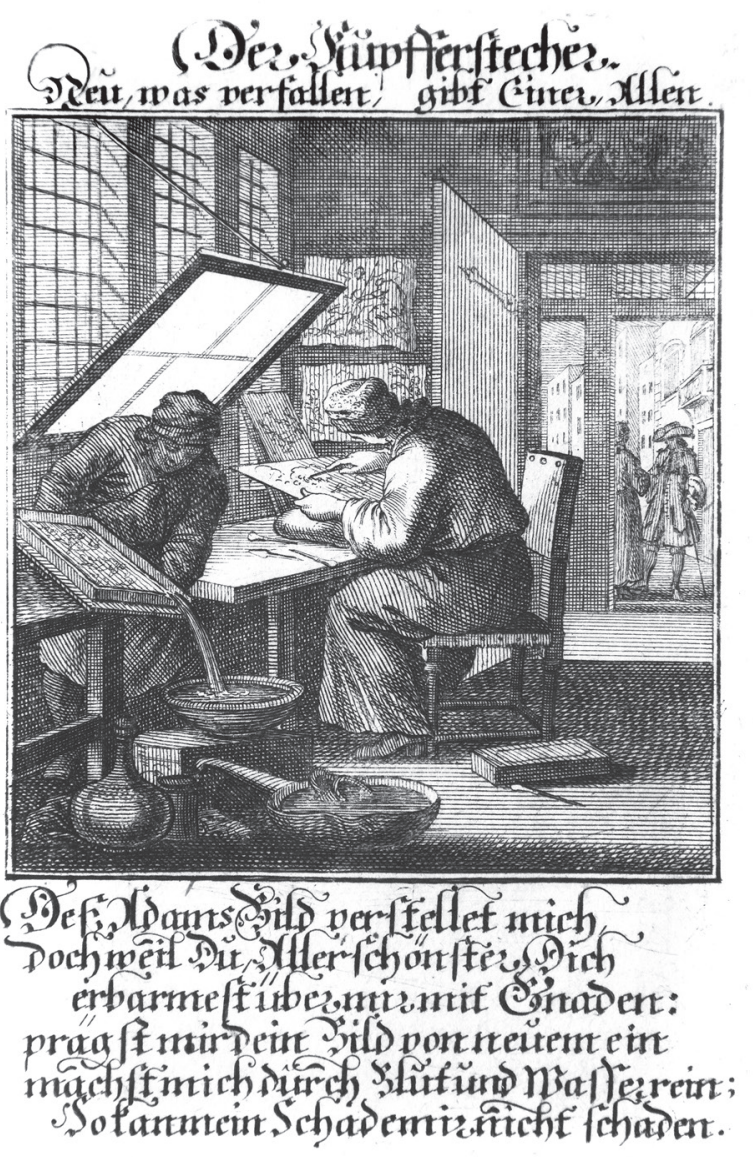

3. Ismeretlen osztrák mester: Rézmetsző munkája közben. Rézmetszet, 1670 körül. A szerző gyüjteményében

Aki Istent, a világot, s a házát szenvedélyesen szereti és tiszteli,

A legritkább kincseket ássa ki, müvészeket foglalkoztatva képez és nevel;

Emlékműre és hálára méltó: az a Pfeffel, kinek nevét hallva,

A kiadóját vésnöki íróvesszejével együtt, kívánja arcát is megismerni.

Egy hű fiú így szolgálván a világot és betöltve tisztét, Köszönettel mutatja be atyja arcát,

És kívánja, hogy Isten áldásával virulj még sokáig,

Hogy Istennek, a tudós világnak és nekünk a te örömöddel szolgálj. ${ }^{4}$

A rézmetsző műhelyt a benne folytatott munkával mutatja be gyüjteményem két következő, 1670 körüli rézmetszete. Az első a vésnök mestert ábrázolja segédjével, az ajtóban talán a megrendelő várakozik. A második már a kész nyomtatott lapokat tárja az egykorú grafikai múhelyek iránt érdeklődők elé (3-4. kép).

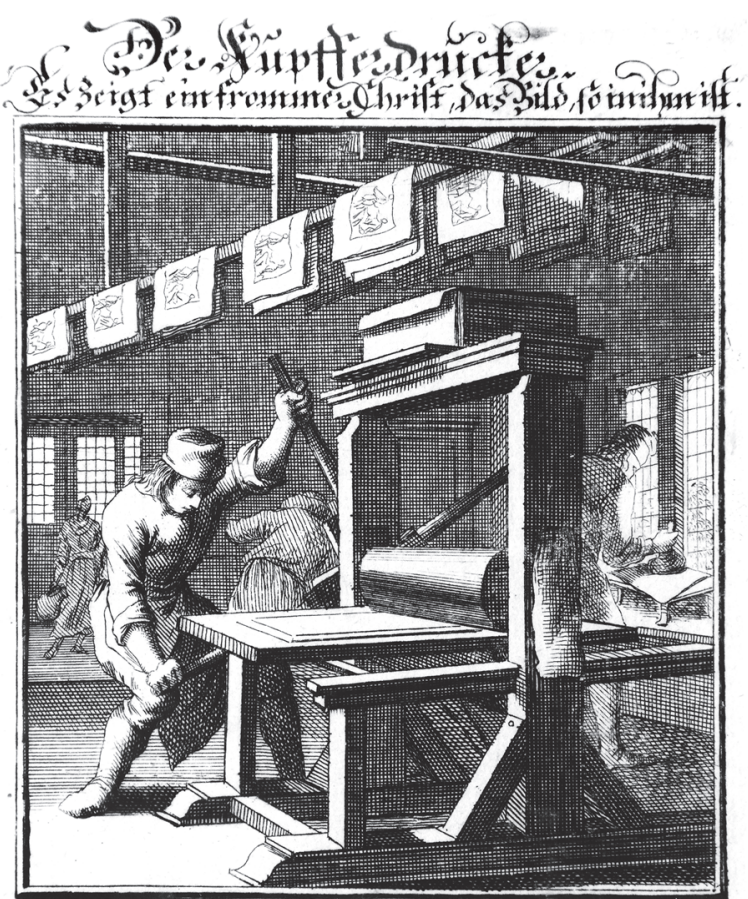

S9)

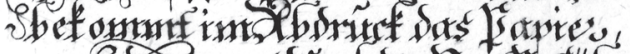

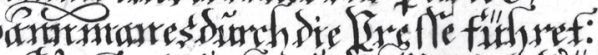

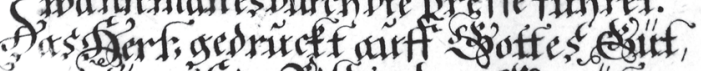

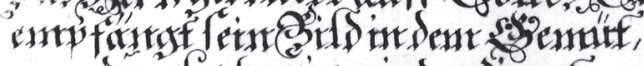

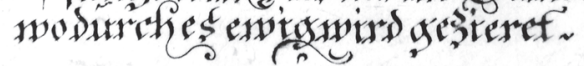

4. Ismeretlen osztrák mester: A rézmetsző munkájának befejezó fázisa. Rézmetszet, 1670 körül. A szerző gyüjteményében

A továbbiakban Krisztus-típusokat sorakoztatok fel. Az idős Johann Andreas Pfeffel különleges kompozíciója a Golgota dombján a passió minden tárgya (armatura Christi) fölött álló győztes Üdvözítő, jobbjában a kereszt koronázta húsvéti zászlóval (Vexilla Regis). Békés mosollyal tekint legkedvesebb tanítványára, aki a mennyei Atyától leeresztett kötélen kapaszkodik, lába az ostorozás oszlopát tiporja, melyhez az Urat kötözték. Az allegorikus kompozíció értelmét a Szent János evangéliumából vett idézet világítja meg: „Senki sem jöhet én hozzám, ha az Atya, ki engem küldött, nem vonzza őt." 6, 44 (5. kép). ${ }^{5}$

Gyüjteményem tematikája miatt is unikális példányán a Halál fölött diadalmas Úr Giovanni Battista Tinti (1558-1604) Jézusát idézi. Festményén a szívsebéből csorduló vért egy térdelő angyal kehelybe fogja fel, lábánál a halált jelentő koponyát tiporva, töviskoszorús keresztjét öleli. A kitünő pármai manierista művészt Michelangelo Rómában, a S. Maria sopra Minervában álló Krisztusa ihlette (6. kép). ${ }^{6}$ 


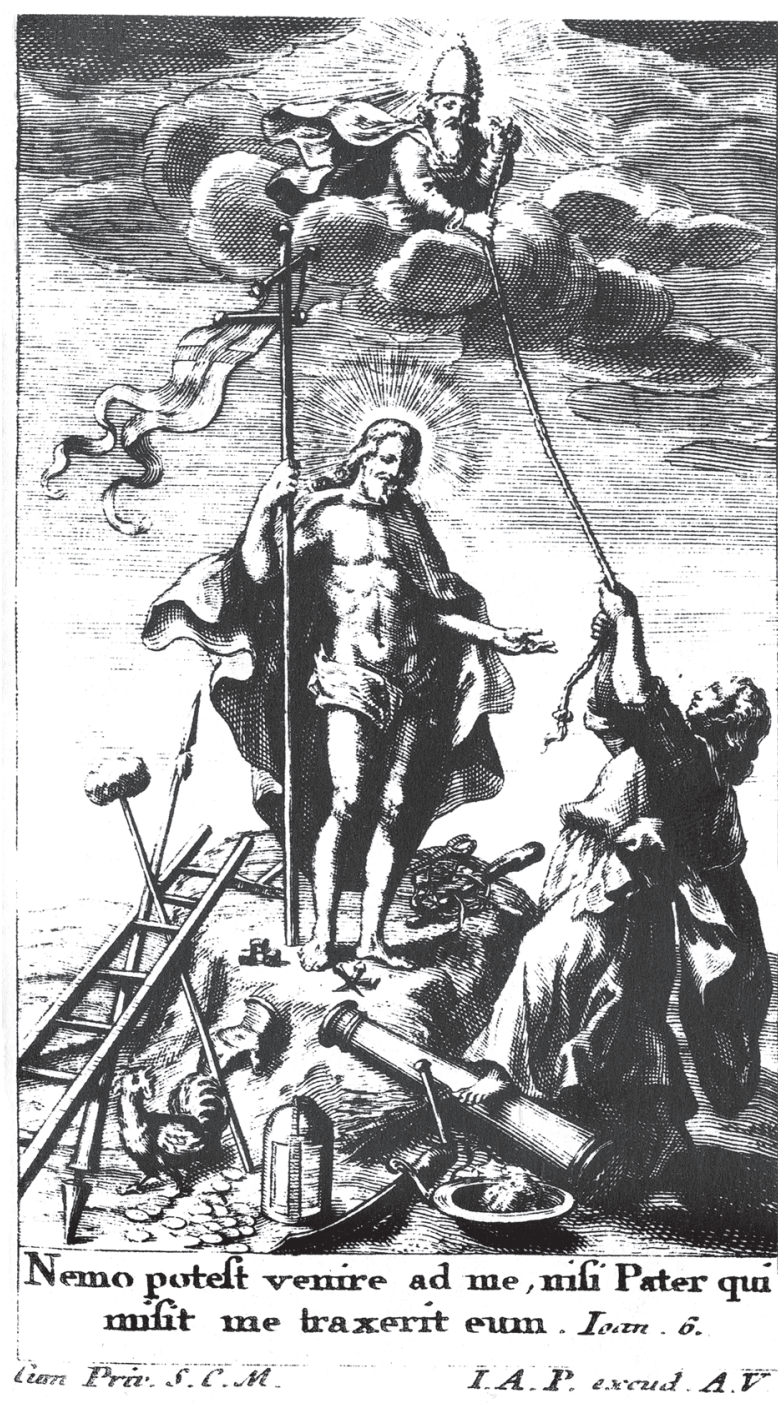

5. Id. Johann Andreas Pfeffel: A kínhalála fölött gyözedelmes Krisztus allegóriája. Rézmetszet, 1720 körül.

A szerző gyüjteményében

A szokatlan témákat kedvelő Pfeffel egy könyvillusztrációján a megdicsőült Üdvözítő oldalából fakadt vért és vizet mint a szentmiseáldozat anyagát szemlélteti, amit adoráló angyalok kehelybe, illetve kancsóba fognak fel (7. kép).

Binder János Fülöp (1736/37-1811) 1689 után az első Pozsonyból Budára telepedett rézmetsző, aki számtalan megrendelésnek tett eleget. A Vízivárosban az Erzsébet-apácák, korábban franciskánusok templomának jobb oldali első oltárán tisztelték a tiroli Matrei ma is meglévő Vir Dolorumkegyszobrának festményváltozatát, amelyről Binder szentképet készített (8-9. képek). ${ }^{8}$ Prototípusa a Matrei-beli régi plébániatemplom főoltárán álló 14. századi, aranyhímzésű vörös palásttal ékesített kegyszobor (10. kép). ${ }^{9}$ Kezeit a torinói Szent Lepel mintájára maga elé tartja.
Eszmefuttatásom végére hagytam a számomra legnagyobb művész, Michelangelo Buonarroti (14751564) két monumentális alkotásának értelmezését. A halála négyszázötvenedik évfordulóját ünneplő Kapitóliumi Múzeum (Musei Capitolini) kiállításának molinójára a Győztes Jézus mellképét nyomták Bassano Romanóból, amely a mester közismert S. Maria sopra Minerva-beli Krisztus-szobrának nemrég felfedezett - és szintén jubiláló - előzményeként kapott helyet 2014-ben a nagyszabású tárlaton. ${ }^{10}$

A Bassano Romanó-i Jézust Michelangelo jóval korábban, egész fiatalon készítette, és a sopra Mi-

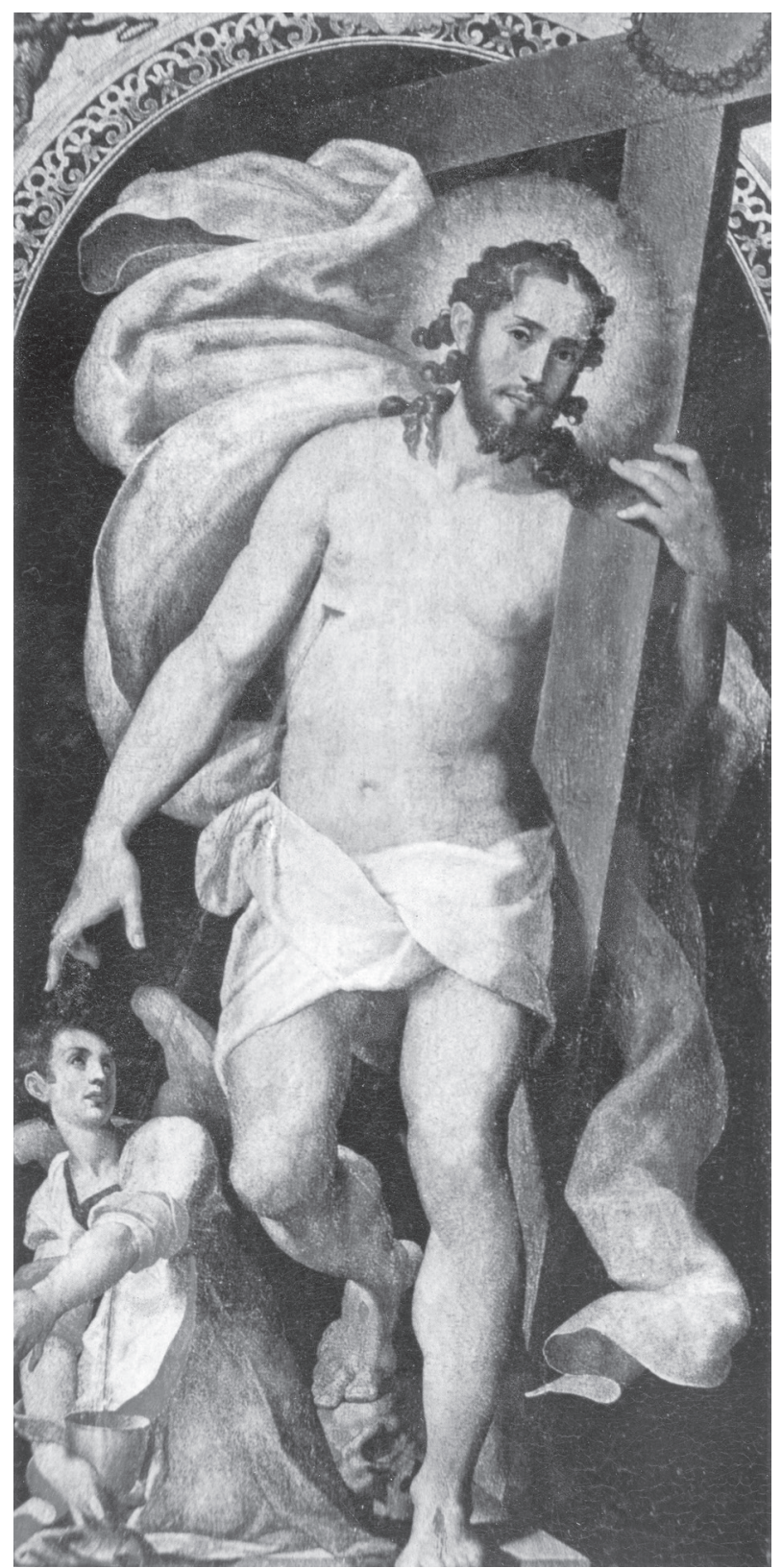

6. Giovanni Battista Tinti: A Halált tipró, átszúrt szívének vérével éltető föltámadt Jézus. Festmény, 1580 körül. Párma, Pinacoteca 


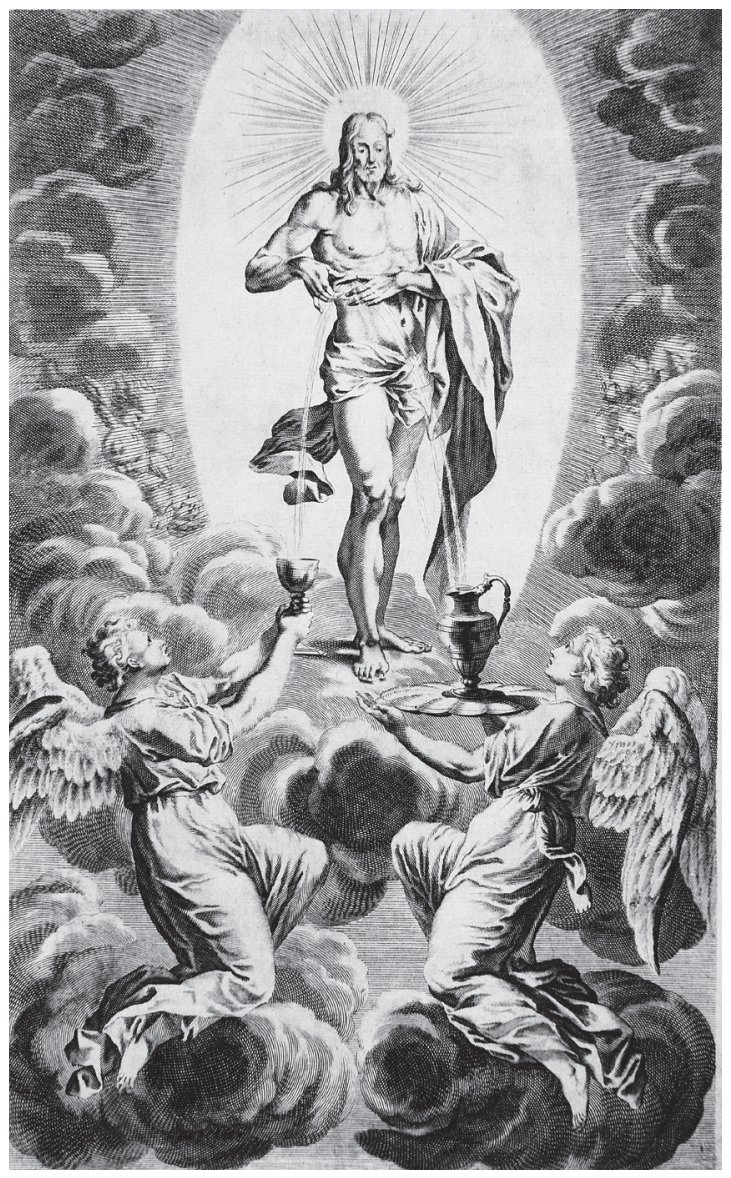

7. Id. Johann Andreas Pfeffel: A megdicsőült Krisztus oldalából fakadó vér és víz az Eucharisztia szineit képezi.

Rézmetszet, 1715 körül. A szerző gyüjteményében

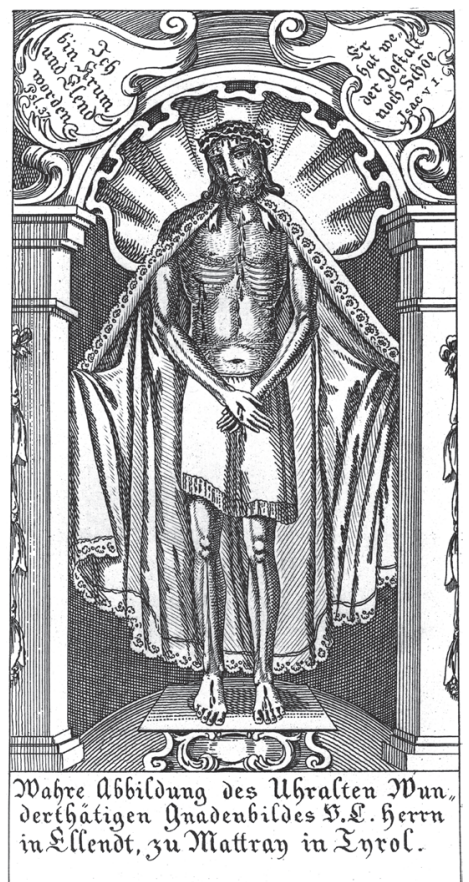

9. Binder János Fülöp: A Budán tisztelt Fájdalmas Krisztus-kegykép. Rézmetszet, 1770 körül

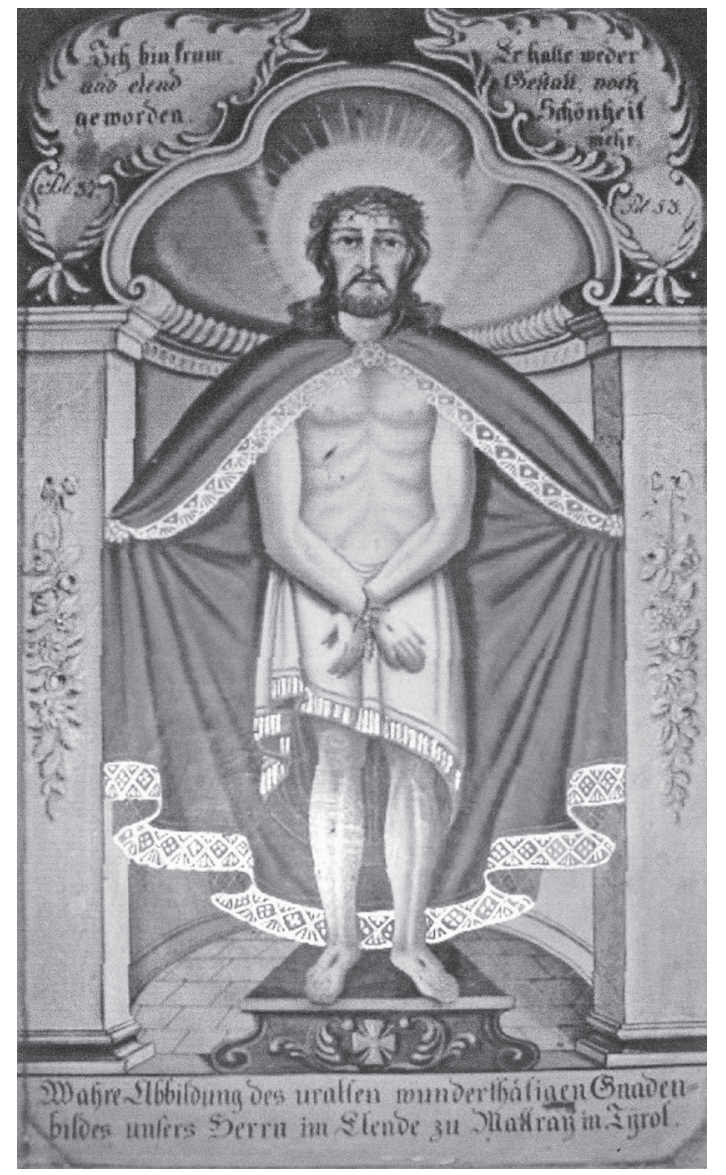

8. Magyarországi festő: A Matrei Vir Dolorum festményváltozata. Olaj, vászon, 1750 körül.

Budapest, Szent Ferenc Sebei-templom

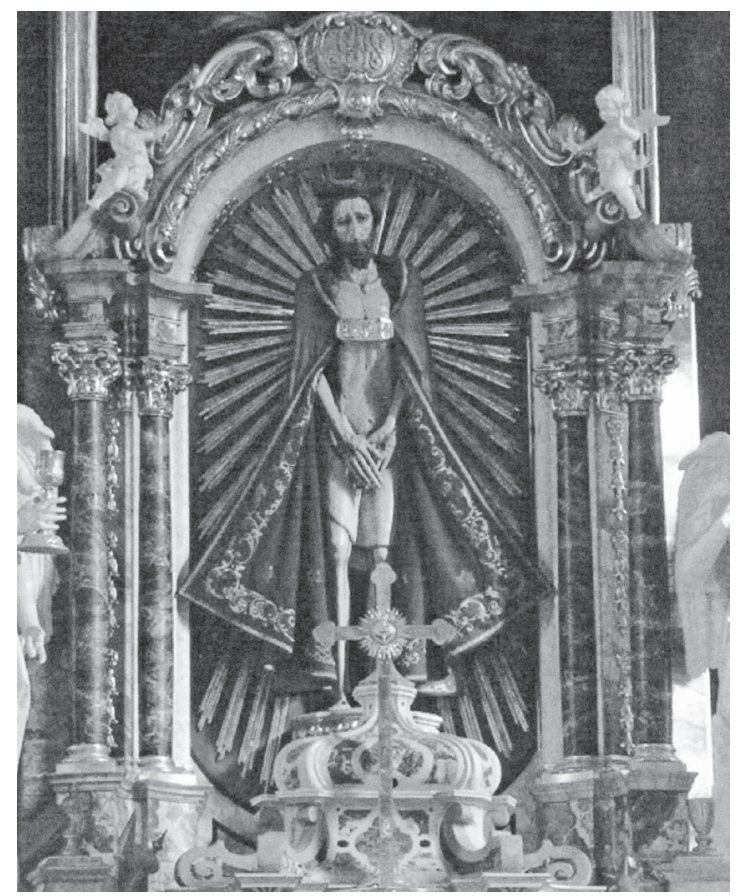

10. Osztrák szobrász: A Matrei-beli öltöztetett kegyszobor. Festett fa, 1360 körül. Pfons (Tirol), plébániatemplom 
nerva-templom szobra első verziójának tekinthető. Mindkettőn a húsvét misztériuma van kifejezve. $\mathrm{Az}$ attribútumok egyezésének sajátos üzenete van. A kereszt dominanciája természetes. A kötelek, a szivacs, az ágyékkendő meztelenségük miatt ugyancsak fellelhető, de a korábbi szobor bal kezénél a gúnypalást hullik alá a támasztékul is szolgáló ostorozás oszlopára (11. kép).

A S. Maria sopra Minerva alaposabban kidolgozott, szintén életnagyságot meghaladó fehérmárvány szobrán a Feltámadott Úr mindkét keze

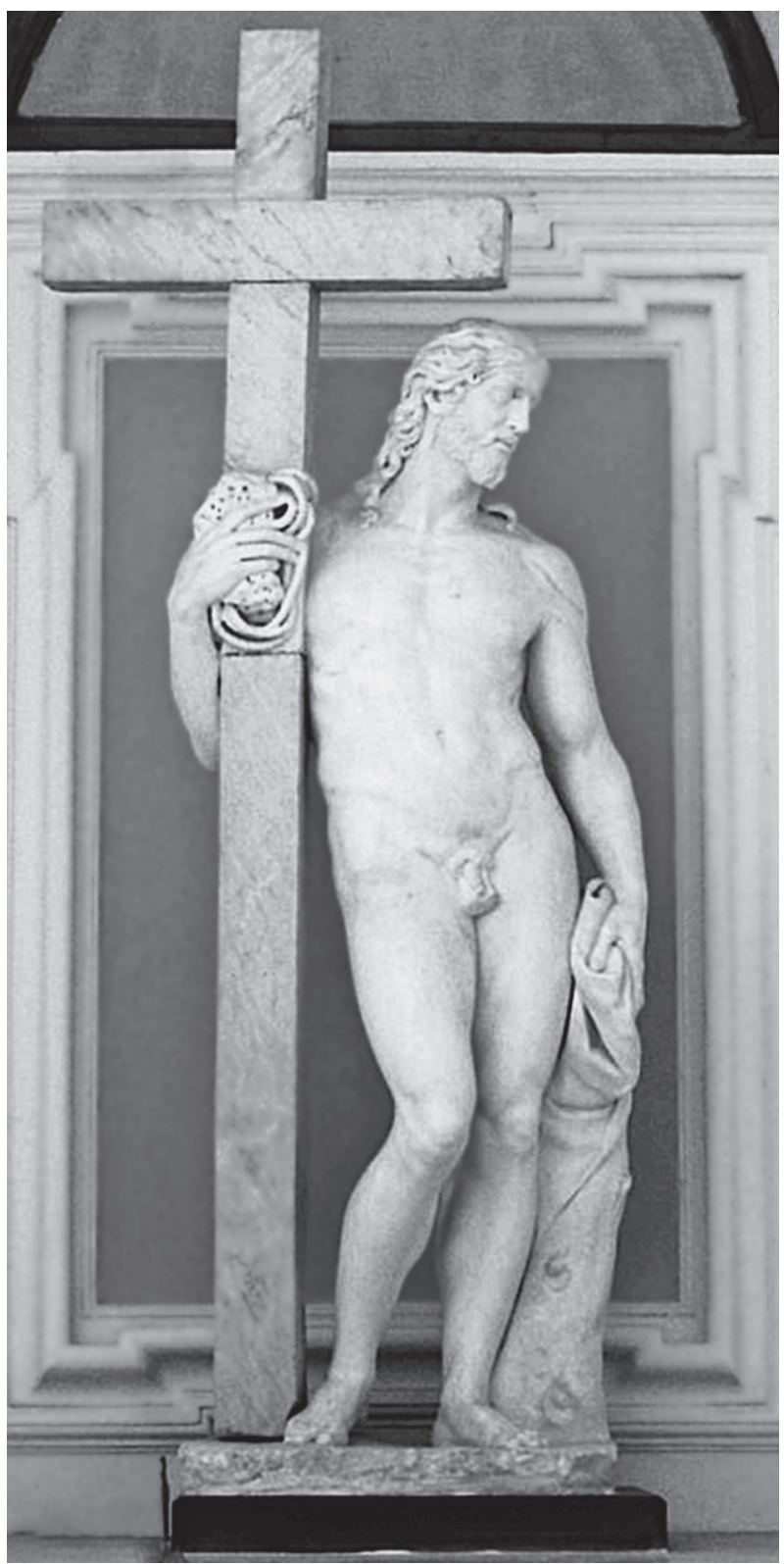

11. Michelangelo Buonarroti:

A megváltó Krisztus a szenvedéstörténet tárgyaival. Fehér márvány, 1514-1516. Bassano Romano, San Vincenzo Martire a kereszthez szorítja a passióból ismert nádszálat a spongyával, továbbá a kötelet az ágyékkendővel. A 68. zsoltár jövendölése szerint „Enni nekem epét adtak, és szomjúságomban ecettel itattak". Figyelemre méltóak a megrendelés körülményei: Bernardo Cencio vatikáni kanonok és Metello Vari még 1514-ben megrendelték Michelangelónál a templom számára. A munkaidőt négy esztendőben, az árat pedig 200 aranydukátban szabták meg. Michelangelo nem volt megelégedve a márvánnyal, és hamarosan egy másik

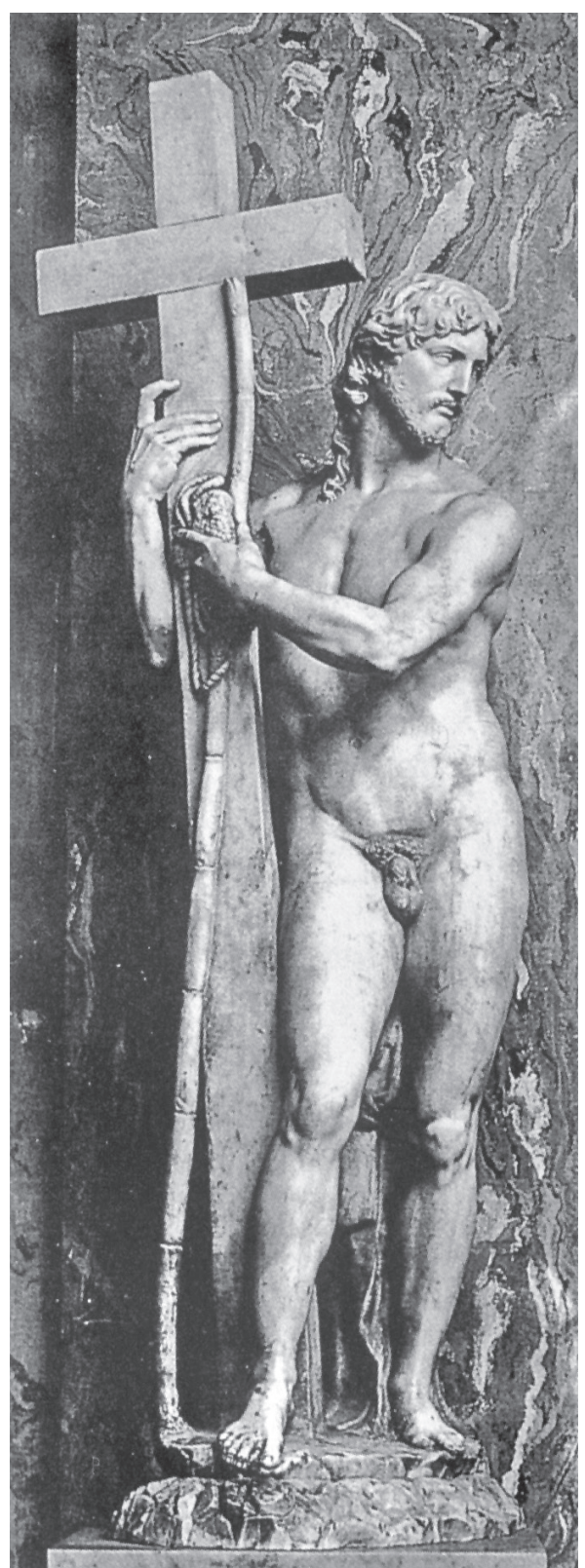

12. Michelangelo Buonarroti:

A megváltó Krisztus a passió attribútumaival. Fehér márvány, 1521. Róma, S. Maria sopra Minerva 
szobor megfaragásába kezdett. Források szerint - sok sürgetésre - csak 1521 júniusában küldte el Firenzéből Rómába a be nem fejezett szobrot. Egy Pietro Urbano nevű szobrász próbálta kidolgozni, de vésője sok hibát ejtett rajta, amit a mesternek kellett rendbe hoznia. Csak ekkor, vagyis 1521. december 27-én történhetett meg a szobor leleplezése (12. kép). ${ }^{11}$

Kortársak tanúsága szerint 1521-ben mindkét szobor Rómában volt látható: a második verzió a templomban, az első, még mindig befejezetlen pedig Metello kertjében. Ezt helyeztette 1644-ben Andrea Giustiniani a Bassano Romanó-i San Vincenzo Martire-templom főoltárára, ahonnan 1979-ben került a sekrestyébe, majd újrafelfedezése után, 2002ben a jobb oldali kápolnába. ${ }^{12}$

$\mathrm{Az}$ alkotáson nem csupán támasztékként egy oszlop is szerepel. A római Szent Praxedis-bazilika Szent Zénó-kápolnájából nyíló kis helyiségben középen egy vörös jáspisból való, alacsony (kb. 70 $\mathrm{cm})$ oszlop áll. Giovanni Colonna bíboros, az 5 . keresztes hadjárat (1219) pápai seregének vezére hozta magával a Szentföldről, és 1223-ban itt, az ő tituláris templomában állította föl. Ez lenne Jézus megostorozásának oszlopa. Hitelességét bizonyítani nem lehet, mégis föltűnő, hogy Szent IX. Lajos francia király elkérte a pápától azt a vasgyưrüt, ami körülvette eredetileg ezt az oszlopot, és cserébe a legendás ereklyéből, Krisztus töviskoszorúja ereklyéjéből három tövist ajándékozott a templomnak. Lajos a töviskoszorú-ereklye tiszteletére építtette a párizsi Sainte Chapelle-t 1246-1248 között. ${ }^{13}$

Alexiosz I. Komnénosz görög császár 1092-ben felsorolja a Konstantinápolyban őrzött ereklyéket. A bíborpalást és a nád már ott is szerepel. Egy 1200-ból való jegyzék a Hagia Sophia szentélyében a szivacsot, a bíbor chlamyst, a nádszálat már említi. Miután a számtalan ereklye Rómába került, a lateráni Sancta Sanctorum ereklyetárában megtaláljuk a nádszálat az ecetes spongyával, amit a haldokló Krisztusnak nyújtottak a kereszten.

A középkori Európa legjelentősebb, Nagy Károly kegyes ajándékaival elhalmozott ereklyetárában, az aacheni Dómban az Úr ágyékkendőjét is őrizték (Perizonium Domini). Erre nem figyeltek fel a kutatások, pedig búcsúnyerés céljából még a 16 . században is felkeresték az akkor ismert világ zarándokai, tehát feltétlen fontosnak számított. ${ }^{14}$

A több színben ragyogó példák felvonultatása grafikatörténeti ritkaságokból kiindulva, manierista Krisztus-típusokon át Michelangelóig - szerezzen örömöt az olvasónak!

\section{JEGYZETEK}

1 Dedek Crescens Lajos: Szentek élete. Budapest 1900. I. 32-33.

2 Uo. 279-280; Íjjas Antal: Szentek élete. Budapest 1976, 208-209.

3 Szilárdfy Zoltán: Barokk szentképek Magyarországon. Budapest 1984, 36; Szilárdfy Zoltán: Szent Gellért, mint karmelita. Egy különleges győri festmény ikonográfiája. Arrabona 50. 2012, 2. szám, 245-252 (2-3 kép).

4 Gálos Miklós fordítása alapján stilizáltam.

5 Szilárdfy Zoltán: A magánáhítat szentképei a szerző gyújiteményéből. I. 17-18. század. Szeged 1995, 158. kép. Egykorú Krisztus-ábrázolás a kínszenvedés eszközeivel Johann Christoph Böcklin lipcsei mester rézmetszetén. Lásd: Szilárdfy Zoltán: A magánáhítat szentképei a szerző gyűjteményéből. III. Alkalmazott szentképek (16-21. század). Szeged-Budapest 2008, 119. kép.

$6 \mathrm{Az}$ Öt Szent Seb Konfraternitás zászlója nyomán (Parma, Pinacoteca).

7 Szilárdfy i. m. 2008, 312. kép. Az ábrázolás összecseng a Szent Ignácnak tulajdonított, közkedvelt fohász soraival: Anima Christi..., azaz „Krisztus vére éltess engem, Krisztus oldalából folyó víz, moss tisztára engem...". Vö. Szilárdfy Zoltán: Kultusz és tematika a Jézus Társaság barokk művészetében. Hevesi Napló VI. Különszám, Barokk konferenciák II. Szerk. Löffler Erzsébet. 1996, 58, 19. kép.
Ami az id. J. A. Pfeffel rendkívüli témáit illeti, lásd a fenti könyvemben, melyben Jézus mint Nárcisszus tükörképét nézi; Jézus mint Orpheusz a messiási békét az őt körülvevő vadállatokkal szemlélteti (158., 159. képek).

8 Rózsa György: Grafikatörténeti tanulmányok. Budapest 1998, 61, 128, 379. kat. sz.; Némethy Lajos: A BudapestVízivárosi Erzsébetiek. Megtelepedésük századik évfordulója alkalmából. Budapest 1885, 36, előtte az eredeti rézmetszetü képmelléklet.

9 Deutsche Alpensagen. Gesammelt und herausgegeben von Johann Nepomuk Ritter von Alpenburg. Wien 1861, No. 301.

101564 - 2014 Michelangelo. Incontrare un artista universale. Roma, Musei Capitolini, 2014. május-szeptember. Catalogo a cura di Cristina Acidini con Elena Capretti e Sergio Risaliti. Roma 2014, 90-99.

11 Dr. Tóth K. János: Római virágszedés. Müvészettörténeti Társaság, Bécs 1988, 292.

12 1564-2014. Michelangelo, i. m. 276-277. Cat. IV.8 (befejezetlen mü, ismeretlen 17. századi szobrász kiegészítésével, 1514-1516).

13 Tóth i. m. 393.

14 Szimonidesz Lajos: Jézus és Mária ereklyéi II. Budapest 1933, 200-201, 229, 235. 


\section{INTRIGUING ASPECTS OF THE MANNERIST CHRIST TYPES IN GRAPHIC HISTORY}

St John of God is the patron saint of booksellers and bookbinders. An engraving by Joseph Anton Schmidt of Augsburg depicts him, still in civilian clothes, in a baroque printing office of the engraver's time, around 1770. Johann Andreas Pfeffel jr. made an engraved portrait of his father with a German text of 8 lines under it. My collection has two engravings from around 1670 showing engraving workshops.

Hereafter I am going to list types of Christ. In Johann Andreas Pfeffel sr.'s composition the triumphant Saviour is standing on the instruments of Passion on top of Golgotha, with the flag of Easter in his right hand. His favourite disciple is holding to a rope lowered by the Heavenly Father, his feet treading on the column of the flagellation. The meaning of the allegorical picture is illumined by a quotation from St John's Gospel $(6,44)$. The Lord Triumphing over Death is reminiscent of a painting by Giovanni Battista Tinti: the blood flowing from Jesus's heart is gathered by an angel in a cup. Christ's foot is treading on a skull, he is holding his cross with the wreath of thorns. The mannerist painter of Parma drew inspiration from Michelangelo's Risen Christ in Rome's S. Maria sopra Minerva. In a book illustration Pfeffel depicts the blood and water from the side of the transfigured Saviour as the material of the Eucharist, adoring angels gathering it in a chalice and a pitcher.

In Buda's Víziváros district, on the first side altar on the right in the former Franciscan church (later belonging to the sisters of St Elizabeth) a painted version of the votive statue of Vir Dolorum in Matrei in Tyrol, of which János Fülöp Binder made an engraving, was venerated.

Two monumental works by Michelangelo Buonarroti convey the mystery of Easter. The statue of Jesus in Bas- sano Romano was made by Michelangelo earlier (151416) and can thus be taken as precedent to the sculpture of a similar theme in S. Maria sopra Minerva (1521). The dominant attribute is the cross. In the earlier sculpture, in addition to the ropes, sponge and loincloth, the robe of mockery is dropped by Christ's left hand onto the column of his flogging, which also serves as support.

There is a short red jasper column in the middle of a recess opening from the St Zeno chapel in Rome's Basilica di S Prassede. Cardinal Giovanni Colonna, the commander of the papal army of the fifth crusade (1219) brought it home from the Holy Land and set it up in 1223. It is allegedly the column of Christ's flagellation. The Greek emperor Alexios I Komnenos listed the relics kept in Constantinople in 1092: he already mentioned the purple robe and the reed. A register of 1200 includes the sponge, the purple chlamys and the reed in the sanctuary of Hagia Sophia. After the transfer of the relics to Rome, the reed with the sponge could be found in the reliquary of the Sancta Sanctorum in the Lateran. The Lord's loincloth was preserved in the cathedral of Aachen visited by pilgrims for plenary indulgence as late as the $16^{\text {th }}$ century.

SZILÁRDFY Zoltán művészettörténész / art historian, H-1073 Budapest, Barcsay u. 16.

Kulcsszavak: rézmetsző mühely, Joseph Anton Schmidt, Johann Andreas Pfeffel, győzedelmes Krisztus, a Passió tárgyai, ereklyék, matrei kegyszobor, Michelangelo, Megváltó Krisztus szobra / Keywords: engraving workshop, Joseph Anton Schmidt, Johann Andreas Pfeffel, triumphant Christ, instruments of Passion, votive statue of Matrei, Michelangelo, Risen Christ, Cristo Giustiniani 